\title{
GMM estimation of currency substitution in a high-inflation economy: evidence from Turkey
}

\section{Faruk Sel,uk}

To cite this article: Faruk Sel, uk (1997) GMM estimation of currency substitution in a highinflation economy: evidence from Turkey, Applied Economics Letters, 4:4, 225-227, DOI: $10.1080 / 758518499$

To link to this article: http://dx.doi.org/10.1080/758518499

\section{Published online: 02 Nov 2006.}

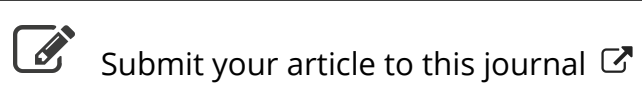

Џll Article views: 43

Q View related articles ¿

4 Citing articles: 7 View citing articles ๘ 


\title{
GMM estimation of currency substitution in a high-inflation economy: evidence from Turkey
}

\author{
FARUK SELÇUK \\ Department of Economics, Bilkent University, 06533 Bilkent, Ankara, Turkey
}

Received 8 May 1996

This paper shows that currency substitution is a first-order importance in a high inflation economy like Turkey. A money-in-the-utility function model is estimated and tested using Hansen's Generalized Method of Moments procedure. The results show that - elasticity of substitution between the Turkish Lira and the US dollar is high and i statistically significant. The estimate of the share of foreign balances in producing $\breve{\circlearrowright}$ domestic money services is considerably large and statistically significant.

\section{INTRODUCTION}

Theoretical models of the currency substitution are simply an extension of money demand models into a multi-currency 를 environment. Most of the empirical studies on currency substitution employ single-equation money-demand-function అ estimates. ${ }^{1}$ Imrohoroğlu (1994) estimates the elasticity of $\vec{a}$ currency substitution between Canada and the United States $\vec{D}$ using a dynamic, equilibrium model of a monetary economy. He finds that there is little evidence of currency substitution between the two countries. He concludes that currency substitution is of second-order importance in a low inflation economy such as Canada, noting that similar analyses for high inflation economies may give different results.

This paper provides new empirical evidence on currency substitution in a high inflation, small economy, namely Turkey. The dynamic approach proposed by Imrohoroğlu (1994) is adopted. In this approach, money enters the agent's utility function because it provides cost reducing services. It is found that the foreign exchange deposits in Turkey are a strong substitute for the Turkish Lira. Furthermore, the estimate of the share of foreign deposits in a Turkish portfolio is considerable high and statistically significant.

\section{THE MODEL}

The model consists of infinitely-lived identical individuals. At the beginning of each period, an individual decides how much to consume, $c_{t}$, how much to save in the form of domestic real bonds, $b_{t}$, and how much to hold in the form of domestic real balances, $\frac{m_{t}}{p_{t}}$, and foreign real balances, $\frac{m_{t}^{*}}{p_{t}^{*}}$. Money services are produced by domestic and foreign real balances in a Constant Elasticity of Substitution production function:

$$
x_{t}=\gamma\left[\alpha\left(\frac{m_{t}}{p_{t}}\right)^{-\rho}+(1-\alpha)\left(\frac{m_{t}^{*}}{p_{t}^{*}}\right)^{-\rho}\right]^{-1 / \rho}
$$

The representative agent maximizes the expected discounted sum of the period-utility function $U$

$$
E \sum_{t=0}^{\infty} \beta^{t} U\left(c_{t}, \frac{m_{t}}{p_{t}}, \frac{m_{t}^{*}}{p_{t}^{*}}\right)
$$

subject to budget constraint

\footnotetext{
1 See Giovannini and Turtelboom (1992) for a detailed survey of the currency substitution literature.

2 It follows from the small economy assumption and the stage of development of the financial markets in the economy that residents do not invest on internationally traded bonds.
} 


$$
\begin{aligned}
c_{t}+\frac{m_{t}}{p_{t}}+\frac{m_{t}^{*}}{p_{t}^{*}}+b_{t} \leq y_{t}-\tau_{t} & +\frac{m_{t-1}}{p_{t}}+\frac{m_{t-1}^{*}}{p_{t}^{*}} \\
& +\left(1+r_{t-1}\right) b_{t-1}
\end{aligned}
$$

where $\beta$ is the discount factor and $c_{t}$ per capita consumption. The real bonds that are bought in period $t$ yield a net real interest rate of $r_{t}$. Each individual receives an exogenous endowment $y_{t}$ and is subject to a lump-sum tax of $\tau_{t}$.

Suppose that the utility function of the representative agent is separable in consumption and liquidity services, and linear in consumption

$$
U(t)=c_{t}+x_{t}
$$

Imrohoroğlu (1994) shows that the estimation equations in this case are

$$
\begin{gathered}
\beta\left(1+r_{t}\right)-1=d_{1, t+1} \\
\alpha \gamma\left[\alpha\left(\frac{h_{t}}{h_{t}^{*}}\right)^{-\rho}+(1-\alpha)\right]^{-1 / \rho-1}\left(\frac{h_{t}}{h_{t}^{*}}\right)^{-\rho-1}+\beta \frac{p_{t}}{p_{t+1}}-1=d_{2, t+1}
\end{gathered}
$$

$$
\alpha\left(1-\beta \frac{p_{t}}{p_{t+1}} \frac{e_{t}}{e_{t+1}}\right)\left(\frac{h_{t}}{h_{t}^{*}}\right)^{-\rho-1}-(1-\alpha)\left(1-\beta \frac{p_{t}}{p_{t+1}}\right)=d_{3, t+1}
$$

where $h_{t}=\frac{m_{t}}{p_{t}}$ and $h_{t}=\frac{m_{t}^{*}}{p_{t}^{*}}$. Note that purchasing power parity is imposed as $e_{t}=\frac{p_{t}}{p_{i}^{*}}$. The right hand sides in Equations 5-7 are the Euler equation errors.

The instrument set consist of the variables entering the estimation equations lagged once

$$
I_{t}=\left\{1, \frac{h_{t-1}}{h_{t-1}^{*}}, \frac{p_{t-1}}{p_{t}}, \frac{e_{t}}{e_{t-1}}, 1+r_{t-1}\right\}
$$

\section{ESTIMATION}

Hansen's (1982) GMM procedure is implemented to estimate the parameters of the Euler Equations 5-7.

Let $d_{t+1}=\left(d_{1, t+1} d_{2, t+1} d_{3, t+1}\right)^{\prime}$, and let $z_{t}$ be the vector of instruments. Then, the following function can be formed using sample information

$$
g_{T}(\theta)=\frac{1}{T} \sum_{t=1}^{T} z_{t} \otimes d_{t}+1(\theta)
$$

where $\theta=(\alpha, \beta, \gamma, \rho)^{\prime}$. The parameter vector can be estimated by minimizing

$$
g_{T}(\theta)^{\prime} W_{T} g(\theta)
$$

where $W_{T}$ is a weighting matrix. Hansen (1982) describes how to obtain a consistent and efficient estimate of the weighting matrix $W_{T}$.
The estimation results are obtained using a non-linear system estimation routine written in RATS (4.2) which automatically obtains the optimum weighting matrix $W_{T}$. Convergence is accepted when the change in parameter vector from one iteration to the next is less than $10^{-5}$. The estimation of the model is converged after few iterations.

\section{DATA AND ESTIMATION RESULTS}

Turkish case is particularly interesting since the economy experiences moderate-to-high levels of inflation with a considerable level of currency substitution (Selçuk, 1994).

The sample period is February 1985-December 1993. Although Turkish residents were allowed to open foreign exchange deposits as of January 1984, the first 12 months are excluded to eliminate any start-off effects. Observations on Turkish money supply M1 $(m)$, foreign exchange deposits by residents in Turkey $\left(\mathrm{m}^{*}\right)$ consumer price index of the State Institute of Statistics of Turkey $(p)$ are obtained from the Turkish Central Bank data base. Monthly real interest rates on domestic bonds $(r)$ are calculated by dividing the gross nominal rates on 3-month Turkish Treasury bills by the gross inflation rate as measured by the rate of increase in consumer price index in Turkey. Monthly observations on the US price level $\left(p^{*}\right)$ is obtained from the IFS tapes.

$J$-statistic - which is the sample size times the minimized value of the function (10) - is computed in order to test overidentification restrictions. This test has a $\chi^{2}$ distribution with 11 degrees of freedom. Overidentifying restrictions of the model are rejected at a very small significance level.

The $C$-statistic, proposed by Eichenbaum et al. (1988) and used by Imrohoroğlu (1994) is obtained to test the null hypothesis of $\alpha=1.0$. This statistic is calculated as the differences between the $J$-statistics form the restricted and unrestricted models. It is a $\chi^{2}$ variable with 1 degree of freedom. The $C$-test rejects the null hypothesis of $\alpha=1.0$ at a

Table 1. Estimation results

\begin{tabular}{lc}
\hline Parameter $^{\mathbf{a}}$ & Estimation \\
\hline$\alpha$ & 0.703 \\
& $(0.021)$ \\
$\beta$ & 0.9865 \\
$\gamma$ & $(0.0018)$ \\
& 0.0678 \\
$\rho$ & $(0.0044)$ \\
$J(11)$ & -0.6479 \\
& $(0.1012)$ \\
$C_{\alpha}(1)$ & 44.29 \\
& {$[0.000]$} \\
& 14.04 \\
& {$[0.000]$}
\end{tabular}

${ }^{a}$ Asymptotic standard errors are in parnthesis; asymptotic $p$ - values are in brackets. 
very small significance level. This finding gives support to the claim that the currency substitution is of first-order importance in a high-inflation economy such as Turkey.

The estimation results (Table 1) show that the discount factor is statistically significant and less than 1.0. Compared to Imrohoroğlu's estimate for Canada (0.9989), the estimated discount factor for the Turkish case $(0.9865)$ is relatively small, as one would expect in a high inflation economy. The estimate of the share of money services in utility function $(0.0678)$ is also relatively high and statistically significant, indicating that the money services provide transaction cost reducing services. ${ }^{3}$

Contrary to the findings for Canada, the estimate of the share of foreign balances in the production of money services $(0.297)$ in Turkey is quite high and statistically significant. The estimate of $\rho(-0.6479)$ implies an elasticity of currency substitution $\epsilon=\frac{1}{1+\rho}$ equal to 2.418 . Therefore, sample information suggest that foreign exchange deposits are strong ¿ substitute for the Turkish Lira. ${ }^{4}$ In other words, the implicit demand for the US dollar is highly responsive to fluctuations

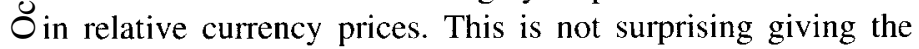

fact that the Turkish economy has been experiencing moderate-to-high levels of inflation $(30 \%-130 \%$ yearly) for the last 15 years, forcing the residents to learn how to live with a domestic currency which looses its basic functions throughout time.

\section{REFERENCES}

Eichenbaum, M.S., Hansen, L.P. and Singleton, K.J. (1988) A time series analysis of representative agents models of consumption and leisure choice under uncertainty. Quarterly Journal of Economics, 103, 51-78.

Giovannini, A. and Turtelboom, B. (1992) Currency substitution. NBER Working Paper, 4232.

Hansen, L.P. (1982) Large simple properties of generalized method of moments estimators. Econometrica, 50, 1029-54.

Imrohoroğlu, S. (1994) GMM estimates of currency substitution between the Canadian dollar and the US, dollar. Journal of Money, Credit, and Banking, 26(4), 792-807.

Selçuk, F. (1994) Currency substitution in Turkey. Applied Economics, 26, 509-18. 